\title{
Oxaliplatin Induces Cell Cycle Arrest and Apoptosis in T-leukemia Cells through Mitochondrial and PI3K/Akt Signaling Pathways
}

\author{
Mengcheng Li, ${ }^{\ddagger, a}$ Yongpeng Wang, ${ }^{\ddagger, a}$ Lei Tian, ${ }^{a}$ Afsar Khan, ${ }^{b}$ Yudan Wang, ${ }^{a, c}$ Yaping Liu, ${ }^{a, d}$ \\ Meilian Yang, ${ }^{a}$ Jianxin Cao, ${ }^{a}$ Guiguang Cheng, ${ }^{*, a}$ and Tianrui Zhao ${ }^{*, a}$ \\ ${ }^{a}$ Faculty of Agriculture and Food, Kunming University of Science and Technology, Kunming, \\ Yunnan 650500, China \\ ${ }^{b}$ Department of Chemistry, COMSATS University Islamabad, Abbottabad Campus, Abbottabad 22060, Pakistan \\ ${ }^{c}$ Yunnan Minzu University, Kunming, Yunnan 650500, China \\ ${ }^{d}$ Kunming Institute of Botany, Chinese Academy of Sciences, Kunming, Yunnan 650500, China
}

Email: chengguiguang@163.com (G. C.), food363@163.com (T. Z.)

¥ These authors have contributed equally to this work.

\begin{abstract}
Oxaliplatin (L-OHP) is a new platinum anticancer drug, which is used for the treatment of metastatic colorectal cancer or the adjuvant treatment of stage III colon cancer. T-cell acute lymphoblastic leukemias (T-ALLs) are invasive thymocytic malignant tumors with poor prognosis. The purpose of this study was to evaluate the cytotoxic effect of L-OHP on human T-ALL cell lines MOLT-4, Jurkat, CCRF-CEM, and CEM/C1 cells. The CCK-8 method results showed that L-OHP significantly inhibited T-ALL cells proliferation. The inhibition of these T-ALL cells prolife by L-OHP seems to be related to the induction of cell cycle arrest. The effect of L-OHP on the cell cycle distribution of T-ALL cells varies with cell types. As to cells apoptosis, Annexin V/Propidium iodide assay disclosed that L-OHP prominently induced T-ALL cells apoptosis by activating the pathways of mitochondrial biogenesis and is more sensitive to MOLT-4 cells. Western blot analysis showed that $\mathrm{L}-\mathrm{OHP}$ treatment could promote apoptosis through down-regulated $\mathrm{Bcl}-2$ protein level, up-regulated $\mathrm{Bax}$ and caspase- 9 proteins levels and cell cycle arrest by inhibiting the PI3K/Akt signaling pathway in MOLT-4 cells. Our results indicate that L-OHP, as a new type of platinum anticancer drug, may attract more attention in the future treatment of T-ALL.
\end{abstract}

Keywords oxaliplatin, lymphoblastic leukemia, mitochondrial pathway, apoptosis, cell cycle

\section{Introduction}

Oxaliplatin (L-OHP) is the third generation platinum drug with better efficacy and lower toxicity than cisplatin and carboplatin, and it can inhibit DNA replication and transcription. ${ }^{[1]}$ The drug has been widely used in the treatment of gastrointestinal malignant tumors. ${ }^{[2]} \mathrm{L}-\mathrm{OHP}$ is also a commonly used anti-tumor drug for many types of solid tumors. ${ }^{[3]}$ Therefore, L-OHP has good potential to be repurposed and developed for the treatment of other malignant tumors.

T-cell acute lymphoblastic leukemias (T-ALL) is a common hematological malignant tumor in children, accounting for $80 \%$ of childhood leukemia cases, and it is also the second most common acute leukemia in adults. ${ }^{[4,5]}$ In the past 20 years, the complete remission rate of initial treatment has remained low, while the fatality rate was high. ${ }^{[6]}$ The 5 -year survival rate is about $30 \%$ for adults and about $90 \%$ for children. ${ }^{[7,8]}$ The standard treatment for T-ALL is a combination of high-dose and multifaceted chemotherapy with different mechanisms including anthracycline, steroids, vincristine, asparaginase, cyclophosphamide, cytarabine and methotrexate. ${ }^{[9]}$ However, these treatments failed in $20 \%$ of children and $50 \%$ of adults. ${ }^{[10,11]}$ Although the treatment of T-ALL has made great progress in recent years, clinical results were still poor. ${ }^{[12]}$ Therefore, it is necessary to further develop new drugs for the treatment of T-ALL.

In this paper, we used four T-ALL cells to evaluate the anti-T-ALL effect of L-OHP by inducing apoptosis and arresting cell cycle. This study may further expand the potential of L-OHP in the treatment of clinically refractory or relapsed T-ALL.

\section{Material and Methods}

\section{Chemicals and reagents}

5,5',6,6'-Tetrachloro-1, 1',3,3'-t-etraethylimidacarbocyanine iodide (JC-1), calcium ion fluorescent probe Fluo-4 AM, and 2',7'-dichlorofluorescin diacetate (DCFH-DA) were purchased from Sigma-Aldrich (Shanghai, China). Hoechst-33258 was purchased from Beyotime (Shanghai, China). Annexin V-FITC/PI apoptosis kit was purchased from Beijing 4A Biotech Co., Ltd. (Beijing, China). Phosphate-buffered saline (PBS), fetal bovine serum (FBS), penicillin, streptomycin, and Roswell Park Memorial Institute (RPMI) 1640 medium were obtained from Gibco (Grand Island, NY)

\section{Cell culture}

Human T-ALL cell lines MOLT-4, Jurkat, CEM/C1 and CCRF-CEM were purchased from the cell bank of Shanghai Institute of Biochemistry and Cell Biology, Chinese Academy of Sciences. The cells were cultured in cell culture medium (500 mL RPMI 1640 plus $10 \%$ fetal bovine serum and $1 \%$ Pen/Strep medium, $37^{\circ} \mathrm{C}, 5 \% \mathrm{CO}_{2}$ humidified) passaged every $5-6 \mathrm{~d}$.

\section{Effect of L-OHP on the viability of T-ALL cells}

The T-ALL cells viability was detected by CCK- 8 method. L-OHP was first prepared in DMSO with a concentration of 10 $\mathrm{mM}$ and then diluted to the respective working concentrations of T-ALL cell in the cell culture medium. In short, four leukemic cells $\left(5 \times 10^{4}\right.$ cells/well) were inoculated into the 96 -cell plate. 
After $48 \mathrm{~h}$ of incubation, $10 \mu \mathrm{L}$ of CCK-8 solution was added to each well and then incubated at $37{ }^{\circ} \mathrm{C}$ for another $4 \mathrm{~h}$. The absorbance was measured with a microplate reader (SpectraMax M5, Molecular Devices, USA) at $450 \mathrm{~nm}$. Cell survival rate was calculated as: Cell survival $(\%)=($ Atreatment $/$ Acontrol) $\times 100 \%$. Half inhibitory concentration $\left(\mathrm{IC}_{50}\right)$ was calculated by Logit regression.

\section{Analysis of apoptosis by AV/PI staining for T-ALL cells}

The T-ALL cells $\left(5 \times 10^{5}\right.$ cells/well $)$ were inoculated in 12-well plates and treated with L-OHP at different concentrations (1, 2 and $4 \mu \mathrm{M})$. The cells were harvested after incubation at $37{ }^{\circ} \mathrm{C}$ for $48 \mathrm{~h}$. Annexin V/PI staining was performed according to the manual provided by the kit manufacturer. $1 \times 10^{5}$ cells L-OHP-treated cells were centrifugal and suspended in $100 \mu \mathrm{L}$ binding buffer provided by the kit for flow cytometry detection. $5 \mu \mathrm{L} \mathrm{AV}$ and PI were added to the cell suspension, incubated for $10 \mathrm{~min}$ at $20-25^{\circ} \mathrm{C}$, diluted to 500 $\mu \mathrm{L}$ with binding buffer, and analyzed by flow cytometry (Guava®easy Cyte 6-2 L, Millipore, Billerica, USA) within $1 \mathrm{~h}$ after staining. All the data were confirmed by three separate experiments.

\section{Cell morphological observation and nuclear Hoechst- 33258 staining for MOLT-4 cells}

The MOLT-4 cells were grouped and treated in the same way as described in the section of "Analysis of apoptosis by AV/PI staining for T-ALL cells". After the cells were treated for $48 \mathrm{~h}$, the 6-well plates were taken out and the morphological changes of the cells were observed under the microscope at 200- and 400-times magnifications. After observing the morphology of cells, the cells were precipitated by $1000 \mathrm{~g}$ centrifugation for $5 \mathrm{~min}$ and then fixed for $10 \mathrm{~min}$ after addition of $0.5 \mathrm{~mL}$ fixing solution. After the removement of the fixed liquid, the cells were washed twice with PBS. Then the cell suspension was dripped on the slide and evenly dripped with $0.5 \mathrm{~mL}$ Hoechst 33258 staining solution for $5 \mathrm{~min}$. The glass slide was covered and observed with a fluorescence Olympus IX83 microscope (Tokyo, Japan) at an excitation wavelength of $350 \mathrm{~nm}$ and emission wavelength of $460 \mathrm{~nm}$.

\section{Determination of $\mathrm{Ca}^{2+}$ in MOLT-4 cells}

The T-ALL cells were grouped and treated in the same way as described in the section of "Analysis of apoptosis by AV/PI staining for T-ALL cells". After $48 \mathrm{~h}$ of treatment, the cells were collected by centrifugation and washed twice with precooled PBS. Then RPMI containing $5 \mu \mathrm{M}$ Fluo-4 AM was used to incubate for $30 \mathrm{~min}$ at $37^{\circ} \mathrm{C}$. After incubation, the cells were washed twice with standard extracellular solution. A $400 \mu \mathrm{L}$ of standard extracellular solution was added to detect the changes of intracellular calcium by flow cytometry (Guava®easy Cyte 6-2 L, Millipore, Billerica, USA) at an excitation wavelength of $488 \mathrm{~nm}$ and emission wavelength of $525 \mathrm{~nm}$.

\section{Detection of mitochondrial membrane potential (MMP) in MOLT-4 cells}

$1 \times 10^{6}$ cells/well of MOLT- 4 cells were inoculated on a 6 -well plate and treated with L-OHP at concentrations of 1,2 and $4 \mu \mathrm{M}$ for $48 \mathrm{~h}$. After incubation, the cells were washed with PBS and stained with $\mathrm{JC}-1$ at $37{ }^{\circ} \mathrm{C}$ for $30 \mathrm{~min}$, during which each 10 min was flipped 6 times so that $\mathrm{JC}$ - 1 was in full contact with the cells. Then it was detected immediately by flow cytometry (Guava®easy Cyte 6-2 L, Millipore, Billerica, USA) at the maximum excitation wavelength of $527 \mathrm{~nm}$ and the maximum emission wavelength of $590 \mathrm{~nm}$.

\section{Effect of L-OHP on MOLT-4 cells cycle}

The T-ALL cells were grouped and treated in the same way as described in the section of "Analysis of apoptosis by AV/PI staining for T-ALL cells". After $48 \mathrm{~h}$ culture, the cells were collected, washed twice with precooled PBS, fixed overnight with $75 \%$ ethanol at $-4{ }^{\circ} \mathrm{C}$, washed twice with precooled PBS, incubated with $0.5 \mathrm{~mL}$ propidium iodide staining solution at $37{ }^{\circ} \mathrm{C}$ for $30 \mathrm{~min}$, and then detected by flow cytometry (Guava®easy Cyte 6-2 L, Millipore, Billerica, USA) at an excitation wavelength $488 \mathrm{~nm}$.

\section{Western blot analysis}

The cells were lysed in $300 \mu \mathrm{L}$ cleavage buffer. The protein extract was loaded on $10 \%$ polyacrylamide gel containing sodium dodecyl sulfate and transferred to polyvinylidene fluoride membrane after electrophoresis. After the membrane was sealed with $5 \%$ skimmed milk for $1 \mathrm{~h}$, the membrane was washed with washing solution 3 times (10 min/time). Then the cells were incubated with specific first antibody for $2 \mathrm{~h}$ at room temperature, and the membrane was washed with membrane washing solution for 4 times (each time for $10 \mathrm{~min}$ ). Proteins were detected by using an enhanced chemiluminescent reagent (Millipore, Billerica, MA, USA) with a VILBER Fusion FX7 imaging system (Vilber Lourmat, Marne-la-Vallée, France). $\beta$-Actin was used to ensure the same load of whole-cell protein. All tests were performed in triplicate. The antibodies used in this study include P-PI3k, PI3k, P-Akt, Akt, Bax, Bcl-2, caspase-9, caspase-3, PARP and $\beta$-actin (1:1000). All antibodies were purchased from Thermo Fisher Scientific.

\section{Statistical analysis}

The data used are expressed as mean \pm SD. All the experiments were repeated for 3 times and Origin 9.0 was used for statistical analysis. One-way ANOVA was used where needed. The value of $p<0.05$ was considered to be statistically significant.

\section{Results}

\section{L-OHP inhibits the proliferation of T-ALL cells and reduces their viability}

As showed in Figure $1(A-D)$ and Table 1, L-OHP significantly inhibited the growth and viability of T-ALL cells in a time- and concentration-dependent manner. There was no significant inhibitory effect on T-ALL cells treated with L-OHP for $12 \mathrm{~h}$. L-OHP treatment for $24 \mathrm{~h}$ only had a significant inhibitory effect on MOLT-4 cells $\left(\mathrm{IC}_{50}=2.50 \pm 0.05 \mu \mathrm{M} ; p<0.01\right)$. As shown in Figure 1, L-OHP treatment for $48 \mathrm{~h}$ had a significant inhibitory effect on Jurkat, MOLT-4, CCRF-C1 and CEM-C1 cells (respective $\mathrm{IC}_{50}=4.15 \pm 0.06 \mu \mathrm{M}, \mathrm{IC}_{50}=1.39 \pm 0.01 \mu \mathrm{M}$, $\mathrm{IC}_{50}=1.55 \pm 0.02 \mu \mathrm{M}$ and $\left.\mathrm{IC}_{50}=6.36 \pm 0.11 \mu \mathrm{M}, p<0.01\right)$, which indicated that it is more sensitive to the inhibitory effect on MOLT-4 cells $(p<0.05)$. The morphological changes of MOLT- 4 cells treated with different concentrations of L-OHP for $48 \mathrm{~h}$ were observed by optical microscope. As the concentration of L-OHP increased, the cell population dispersed and the number of cells decreased. Microscopic observation showed that the MOLT-4 cells without L-OHP treatment were small and round. L-OHP induces multiple death forms in MOLT-4 cells: some cells shrink, the cells are granular, the cell membrane surface germinates, blisters, etc., to form a spherical protrusion, and the cell volume shrinks; some cells also developed vacuoles, marginalized cytoplasm, and increased in volume (Figure 1E).

\section{Analysis of the effect of L-OHP on T-ALL cell lines cycle by flow cytometry}

As shown in Figure 2A, L-OHP and T-ALL cell lines were incubated for $48 \mathrm{~h}$. The results of column chart obtained by flow cytometry revealed that L-OHP had a positive effect on T-ALL cells. The effect of L-OHP on the cell cycle distribution of T-ALL 
(A) Jurkat

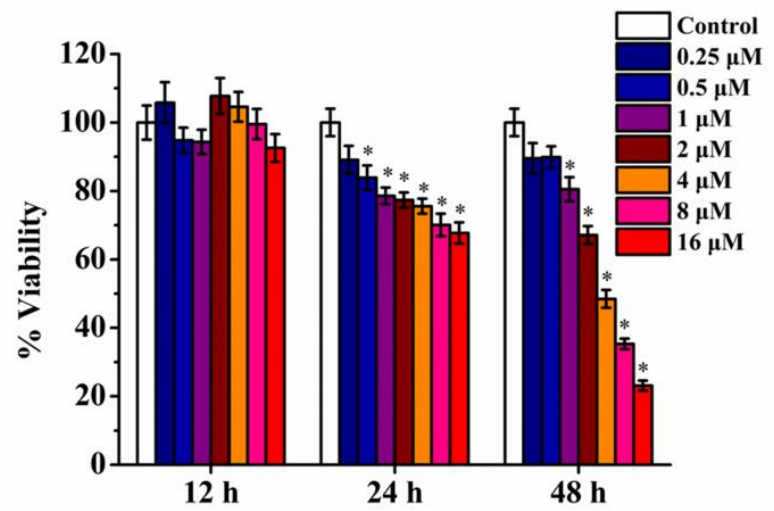

(C) CEM-C1

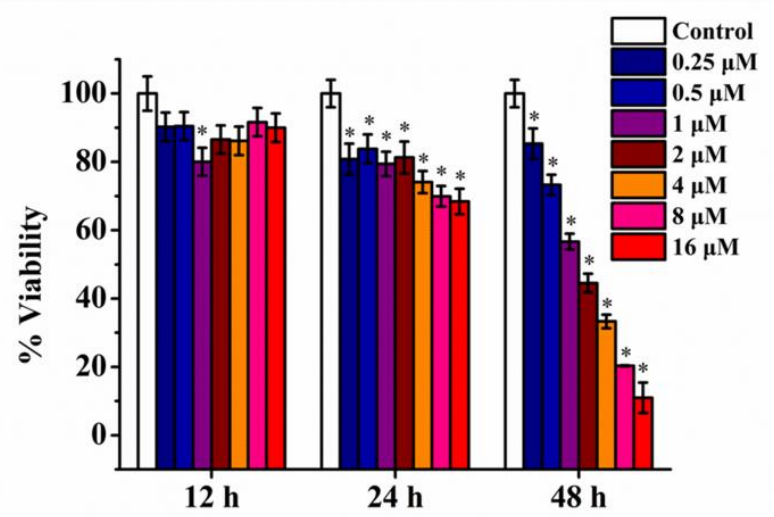

(B) MOLT-4

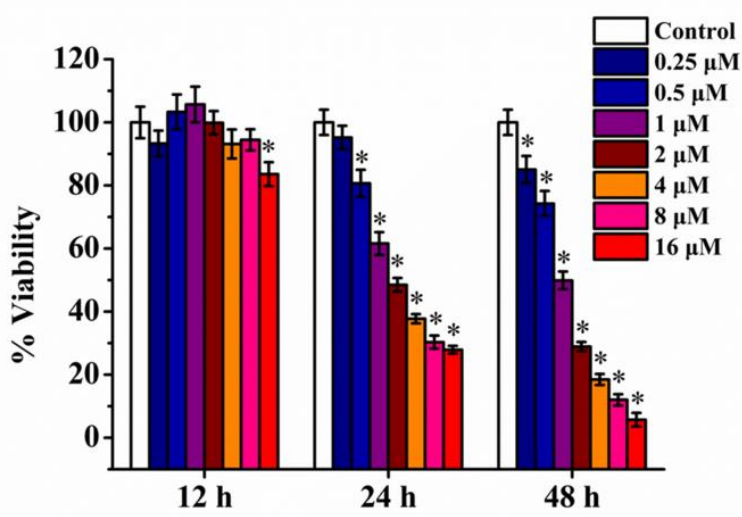

(D) CCRF-CEM

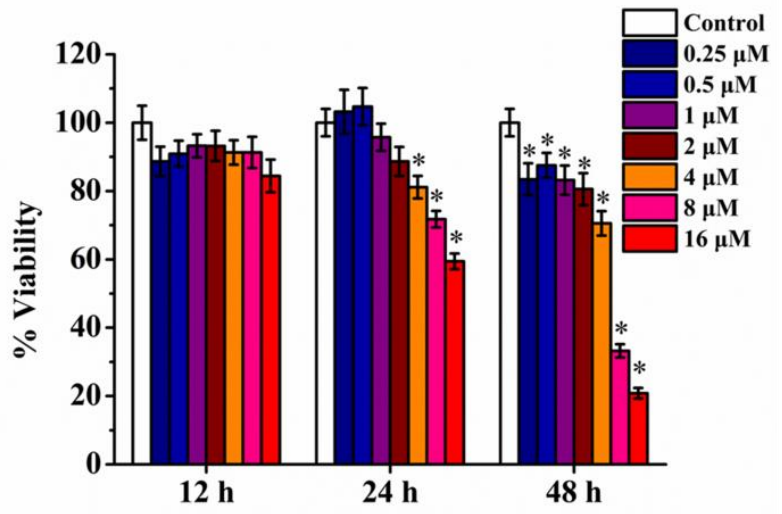

(E) Control
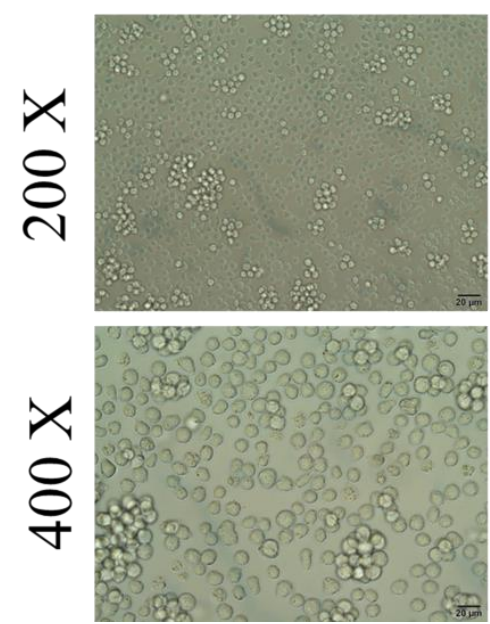

L-OHP $1 \mu \mathrm{M}$
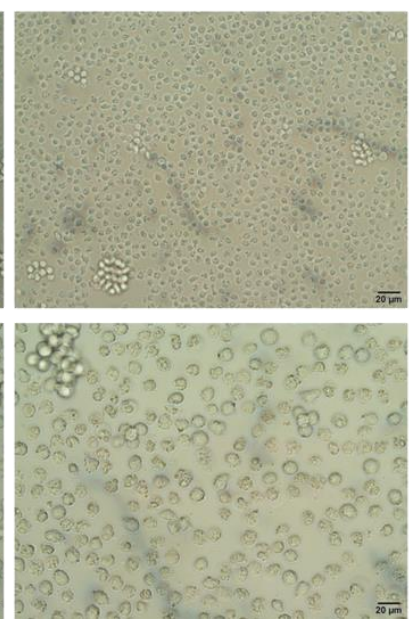
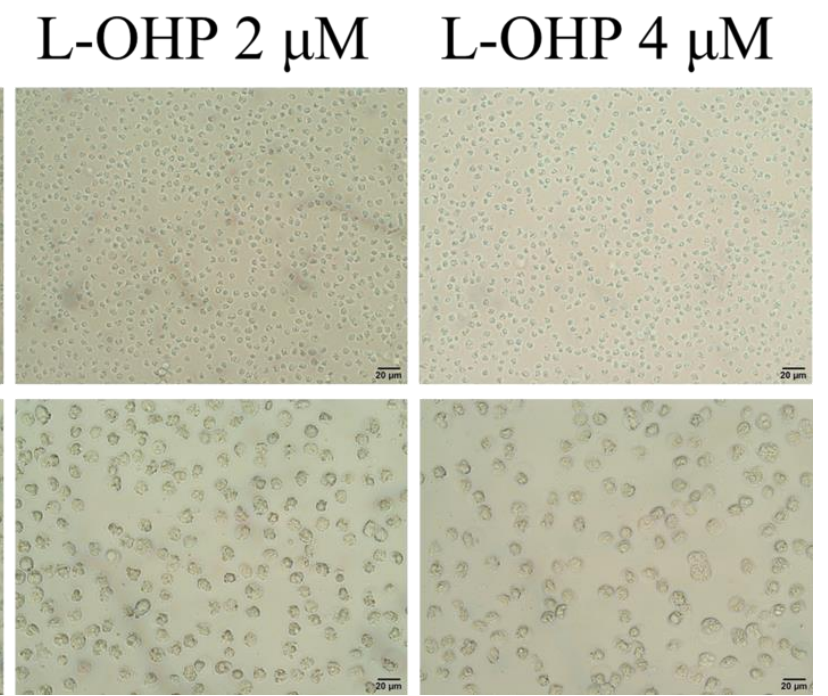

Figure 1 The effect of L-OHP on the cell viability and inhibition of proliferation of T-ALL cell lines. Jurkat, MOLT-4, CEM/C1 and CCRF-CEM cells were treated with $0.25,0.5,1,2,4$ and $8 \mu \mathrm{M} \mathrm{L}-\mathrm{OHP}$ for 12,24 and $48 \mathrm{~h}(\mathrm{~A}-\mathrm{D})$. The cell viability was assessed by CCK-8 assay. (E) Optical image of MOLT-4 cells treated with L-OHP at 1, 2 and $4 \mu \mathrm{M}$ concentrations for 48 h. ${ }^{*} p<0.05$ vs. control group. All data are expressed as the mean \pm SD of more than three independent experiments. 
(A)
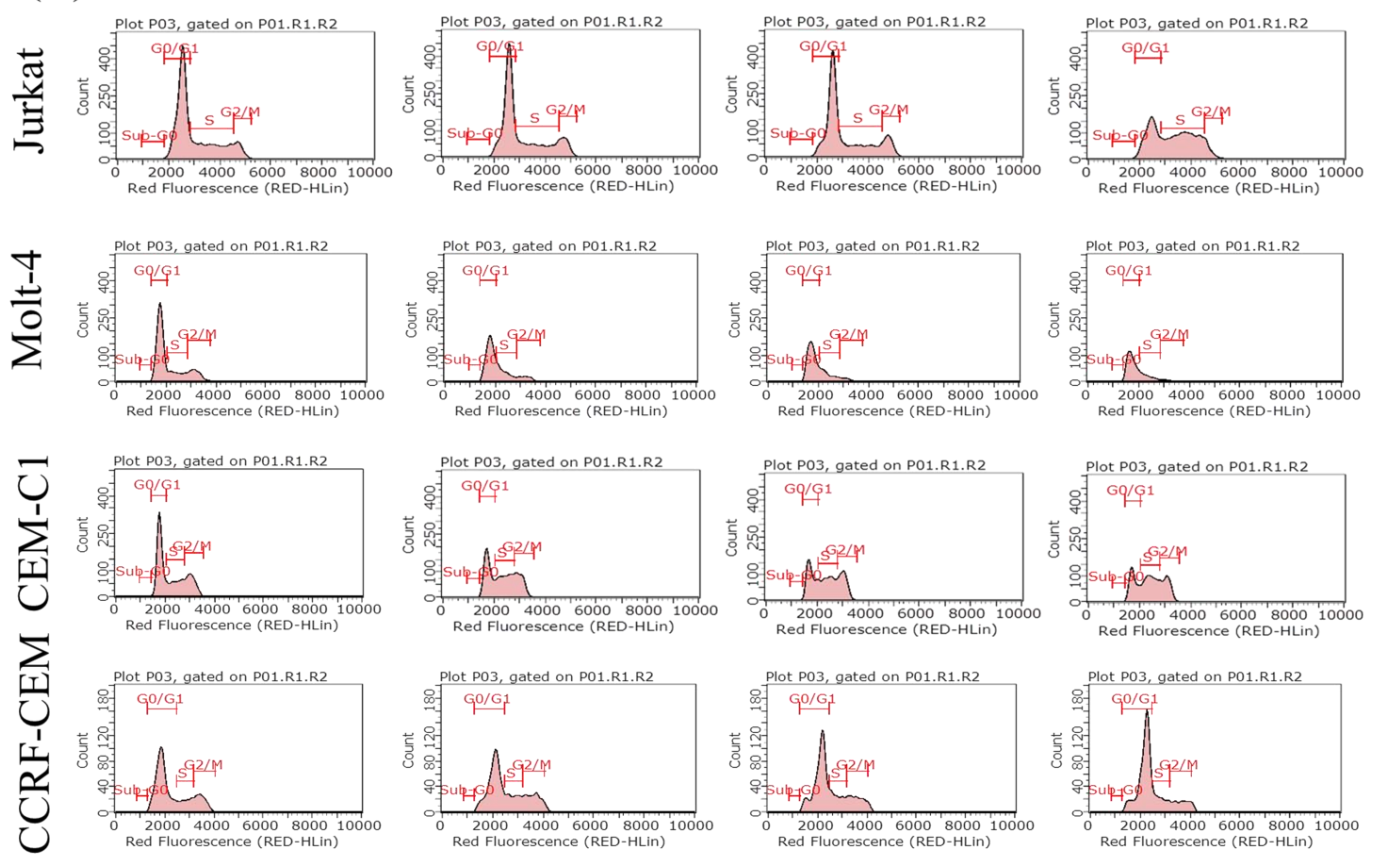

Control

\section{$1 \mu \mathrm{M}$}

$2 \mu \mathrm{M}$

$4 \mu \mathrm{M}$

\section{L-OHP}

(B) Jurkat

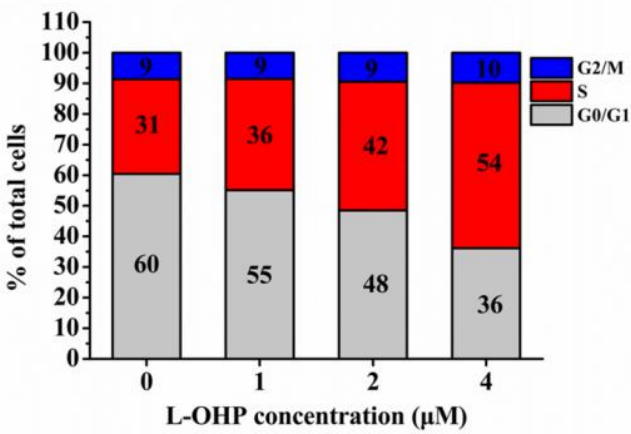

(D) CEM-C1

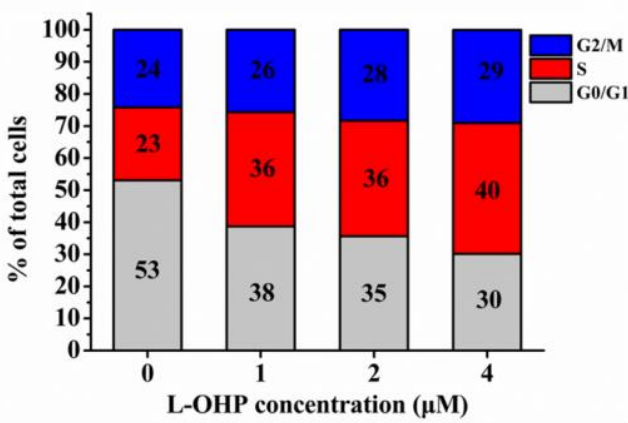

(C) MOLT-4

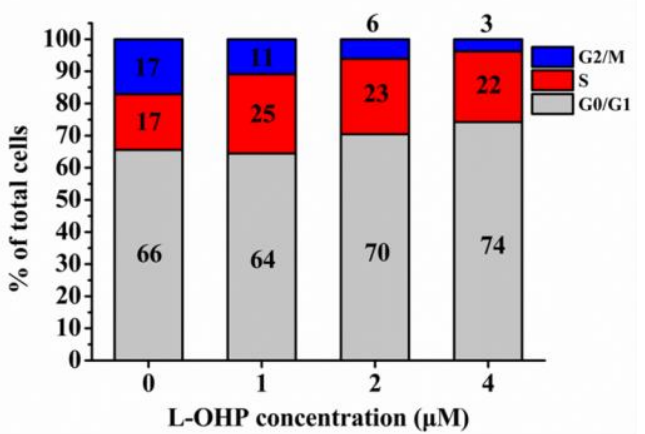

(E) CCRF-CEM



Figure 2 The effect of L-OHP on cell cycle spectrum in T-ALL cell lines. (A) L-OHP triggers the cell cycle of T-ALL cell lines. The cells were treated with continuous concentrations of L-OHP $(1,2$ and $4 \mu \mathrm{M})$ for $48 \mathrm{~h}$. The marked peaks in the figure represent the G0/G1, S and G2/M phases in the cell cycle, respectively. The histograms from (B) to (E) summarize the percentage of cell numbers in each stage of the Jurkat, MOLT-4, CEM-C1 and CCRF-CEM cell cycle after $48 \mathrm{~h}$ of L-OHP treatment. 
Table 1 The $\mathrm{IC}_{50}$ values of T-ALL cells induced by L-OHP at different times

\begin{tabular}{rcccc}
\hline \multirow{2}{*}{ Time } & \multicolumn{5}{c}{$\mathrm{IC}_{50}(\mu \mathrm{M}) \pm$ SD } \\
\cline { 2 - 5 } & Jurkat & MOLT-4 & CEM-C1 & CCRF-CEM \\
\hline L-OHP $24 \mathrm{~h}$ & - & - & - & - \\
$48 \mathrm{~h}$ & $4.15 \pm 0.06$ & $2.50 \pm 0.05^{*}$ & - & - \\
\hline
\end{tabular}

The Jurkat, MOLT-4, CEM-C1 and CCRF-CEM cells were treated with various concentrations $(0.25,0.5,1,2,4$ and $8 \mu \mathrm{M})$ of L-OHP for 12,24 , and $48 \mathrm{~h}$. All data are expressed as the mean \pm SD of more than three independent experiments. ${ }^{*} p<0.05$, Compared with the $\mathrm{IC}_{50}$ value of L-OHP-treated cells of different cell lines.

cell line varied with cell type. L-OHP treatment significantly reduced the percentage of cells in the G0/G1 phase and increased the percentage of cells in the $S$ phases of Jurkat cells (Figure 2B). Under the same L-OHP treatment, the percentage of MOLT-4 cells significantly increased in $S$ phase and significantly decreased in G2/M phase (Figure 2C). The effect of L-OHP on the cell cycle profile of CEM-C1 cells dramatically decreased the percentage of cells in G0/G1 phase and evidently increased the percentage of cells in $S$ phase (Figure 2D). L-OHP treatment significantly increased the percentage of CCRF-CEM cells in G0/G1 phase and markedly decreased the percentage in $\mathrm{G} 2 / \mathrm{M}$ phase (Figure 2E).

\section{L-OHP induces apoptosis in T-ALL cells}

As shown in Figure $3 \mathrm{~A}$, the percentage of apoptotic cells increased significantly in a concentration-dependent manner after L-OHP treatment of T-ALL cells for $48 \mathrm{~h}$. Various concentrations of L-OHP $(1,2$ and $4 \mu \mathrm{m})$ significantly increased the percentage of early or late apoptotic cells in T-ALL cell lines (Figures 3B-3E). Among them, only MOLT-4 cells were significantly induced apoptosis when treated with $1 \mu \mathrm{m} \mathrm{L-OHP}$ $(p<0.01)$, which may indicate that L-OHP is more likely to induce apoptosis in MOLT-4 cells. The MOLT-4 cells were incubated with L-OHP at 1, 2 and $4 \mu \mathrm{m}$ concentrations for $48 \mathrm{~h}$. As shown in Figure 3F, blue fluorescence appeared with chromatin fragments after treating MOLT- 4 cells with L-OHP, indicating that L-OHP markedly induced apoptosis of MOLT-4 cells.

\section{L-OHP induces apoptosis of T-ALL cells through mitochondrial pathway}

As shown in Figure 4A, all doses of L-OHP led to an increase in the green signal of T-ALL cells. It can be seen from the histogram data that L-OHP treatment significantly decreased the MMP of T-ALL cells $(p<0.01)$. The MMP of Jurkat cells decreased from $28.08 \%$ to $2.77 \%$ (Figure 4B), that of MOLT-4 cells decreased from $23.17 \%$ to $1.46 \%$ (Figure $4 \mathrm{C}$ ), that of CEM-C1 cells decreased from $11.1 \%$ to $3.4 \%$ (Figure $4 \mathrm{D}$ ), and that of CCRF-CEM cells decreased from $21.3 \%$ to $4.39 \%$ (Figure 4E).

\section{L-OHP activates calcium influx in T-ALL cells}

As shown in Figure 5A, L-OHP significantly increased the green channel signal intensity of Jurkat cells at a concentration of $4 \mu \mathrm{M}$, and all concentrations of L-OHP significantly increased the green channel signal intensity of MOLT-4 cells in a dose-dependent manner, but the green channel signal intensity of CEM-C1 and CCRF-CEM cells did not change. Histogram data summary showed that $4 \mu \mathrm{M}$ L-OHP significantly increased the calcium concentration in Jurkat cells $(p<0.05)$ and led to a significant increase of calcium concentration in MOLT-4 cells at all doses of L-OHP $(p<0.01)$. However, with L-OHP treatment there was no change in calcium concentration in CEM-C1 and
CCRF-CEM cells (Figures 5B-5E; $p>0.05$ ).

\section{Oxaliplatin inhibited proliferation and promoted apoptosis} in T-ALL cells through PI3K/Akt signaling pathways

In order to further study the mechanism of L-OHP-induced apoptosis of MOLT-4 cells, we used western blotting to analyze PI3K/Akt signaling pathway related proteins. As shown in Figure 6, L-OHP significantly decreased the relative density of $\mathrm{P}-\mathrm{PI3K} / \mathrm{PI} 3 \mathrm{~K}, \mathrm{P}-\mathrm{Akt} / \mathrm{Akt}$ and Bcl-2/Bax $(p<0.05, p<0.01)$, and markedly increased the relative density of caspase- $9 / \beta$-actin, caspase-3/ $\beta$-actin and PARP/ $\beta$-actin in MOLT- 4 cells in a dose-dependent manner $(p<0.05, p<0.01)$.

\section{Discussion}

Loss of cell cycle control and immortal proliferation are the basic attributes of human cancer. ${ }^{[13]}$ Therefore, disrupting the cell cycle by therapeutic agents can cause tumor growth to stagnate and inhibit the cell proliferation, thereby promoting cancer treatment. ${ }^{[14,15]}$ In this study, we found that the effect of L-OHP on the cell cycle profile of Jurkat, MOLT-4, CEM-C1 and CCRF-CEM cells varies with cell types, indicating that L-OHP can induce T-ALL cell apoptosis by inhibiting the cell cycle.

The normal way of cell death is necrosis or apoptosis. Cell necrosis is the physical damage of cells causing the dissolution and disruption of cell membranes and organelles. Apoptosis is a form of programmed cell death, which is characterized by nuclear enrichment and the formation of apoptosis bodies. In the process of cell apoptosis, the membrane is intact, does not release harmful chemical transmitters, and has no negative effect on surrounding cells. ${ }^{[16]}$ Apoptosis is an important event targeted by anticancer drugs. ${ }^{[15]}$ Therefore, we explored whether the growth inhibitory effect of L-OHP is related to cell apoptosis. It was found that L-OHP treatment resulted in a significant level of apoptosis in T-ALL cells in only $48 \mathrm{~h}$.

In the past few decades, the role of mitochondrial homeostasis in tumor growth and metastasis has received increasing attention. ${ }^{[17,18]}$ Compared with normal cells, cancer cells have faster growth and invasive capabilities and require mitochondria to provide more energy. ${ }^{[19]}$ Mitochondrial dysfunction is one of the signs of apoptosis induced by intrinsic pathway. ${ }^{[20]}$ Mitochondria plays an important role in the regulation of apoptosis signals. ${ }^{[21,22]}$ In our experiment, the co-incubation of L-OHP and T-ALL cells for $48 \mathrm{~h}$ resulted in a significant decrease in cell mitochondrial membrane potential, indicating that L-OHP induced Jurkat, MOLT-4, CEM-C1 and CCRF-CEM cells activate via the pathways of mitochondrial biogenesis.

Calcium ion is an important second messenger in cells and plays an important role in protein synthesis, signal transduction, gene expression and apoptosis. ${ }^{[23]}$ Intracellular calcium homeostasis is essential for cells to maintain their normal structure and function. If the endoplasmic reticulum calcium homeostasis changes, cell apoptosis is initiated through the endoplasmic reticulum pathway. ${ }^{[2]}$ In this study, compared with the other two types of cells, L-OHP treatment significantly increased the intracellular calcium concentration of Jurkat and MOLT-4 cells, indicating that L-OHP induces Jurkat and MOLT-4 cell apoptosis, which may involve the intracellular calcium ion concentration increase. It is worth noting that L-OHP did not significantly affect the changes in the intracellular calcium ion concentration of the CEM-C1 and CCRF-CEM cells. Herein, we speculate that L-OHP may induce apoptosis of two cells through the mitochondrial pathway.

In order to further explore the mechanism of L-OHP. 


\section{(B) Jurkat}

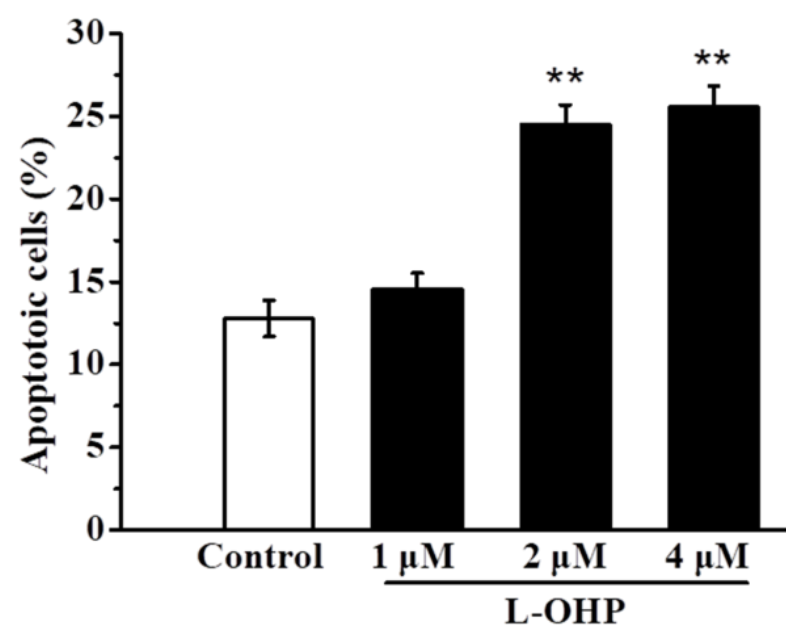

(D) CEM-C1

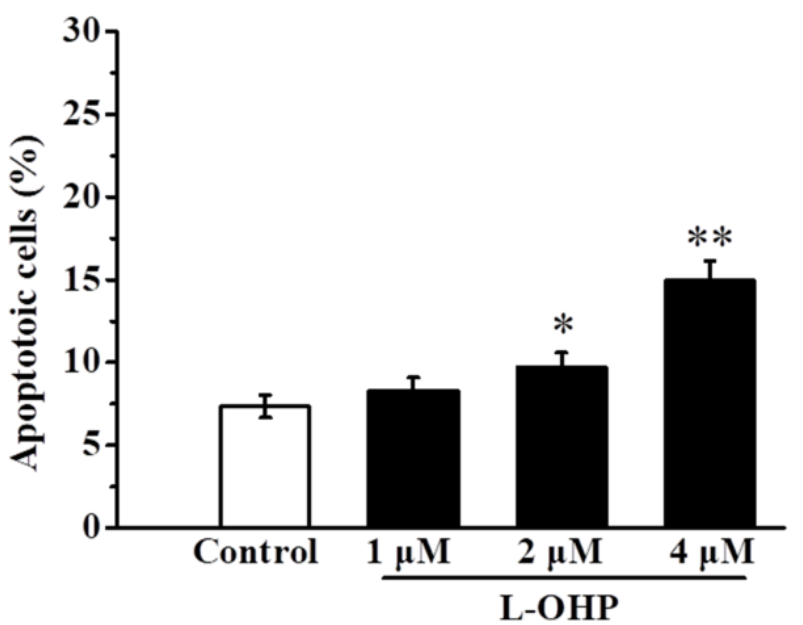

(C) MOLT-4

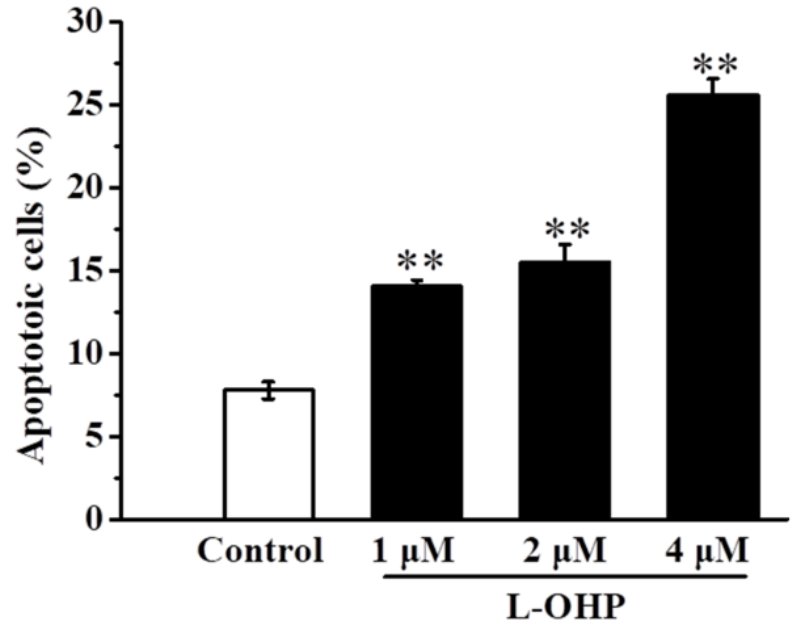

(E) CCRF-CEM

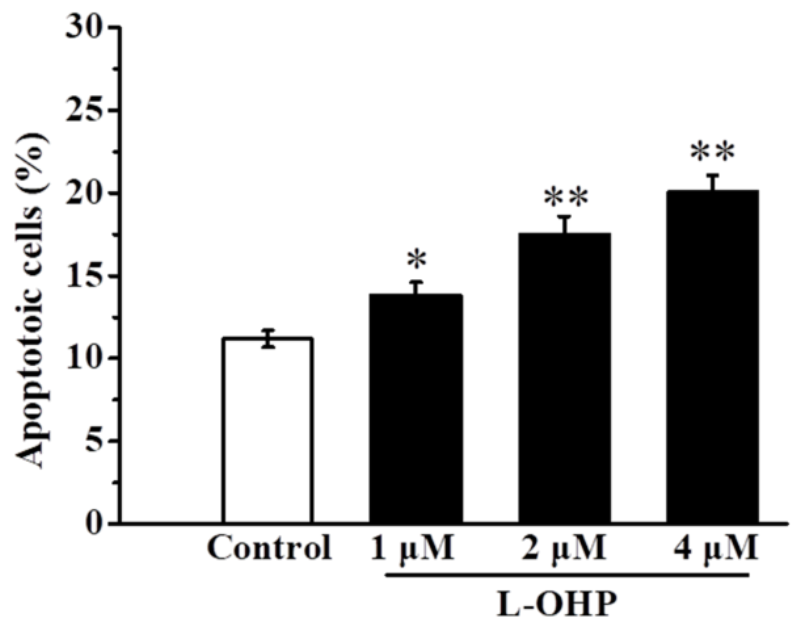

(F)

n
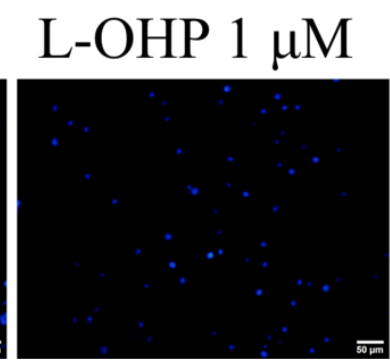


L-OHP $4 \mu \mathrm{M}$

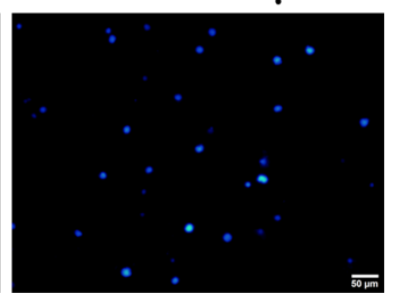

Figure 3 L-OHP induces apoptosis of T-ALL cells. (A) Dot plot analysis of T-ALL cells treated with L-OHP. The cells were treated with 1, 2 or $4 \mu \mathrm{M}$ of L-OHP for $48 \mathrm{~h}$, and stained with Annexin V/PI, and then detected by flow cytometry. (B), (C), (D), (E) percentage of apoptotic Jurkat, MOLT-4, CEM-C1 and CCRF-CEM cells treated with different concentrations of L-OHP at $48 \mathrm{~h}$. (F) MOLT-4 cell nuclear damage confirmed by Hoechst-33258 staining analysis. L-OHP significantly induced early and late apoptosis $\left({ }^{*} p<0.05\right.$ and $\left.{ }^{* *} p<0.01\right)$. Data is expressed as the mean \pm SD of three independent experiments. 

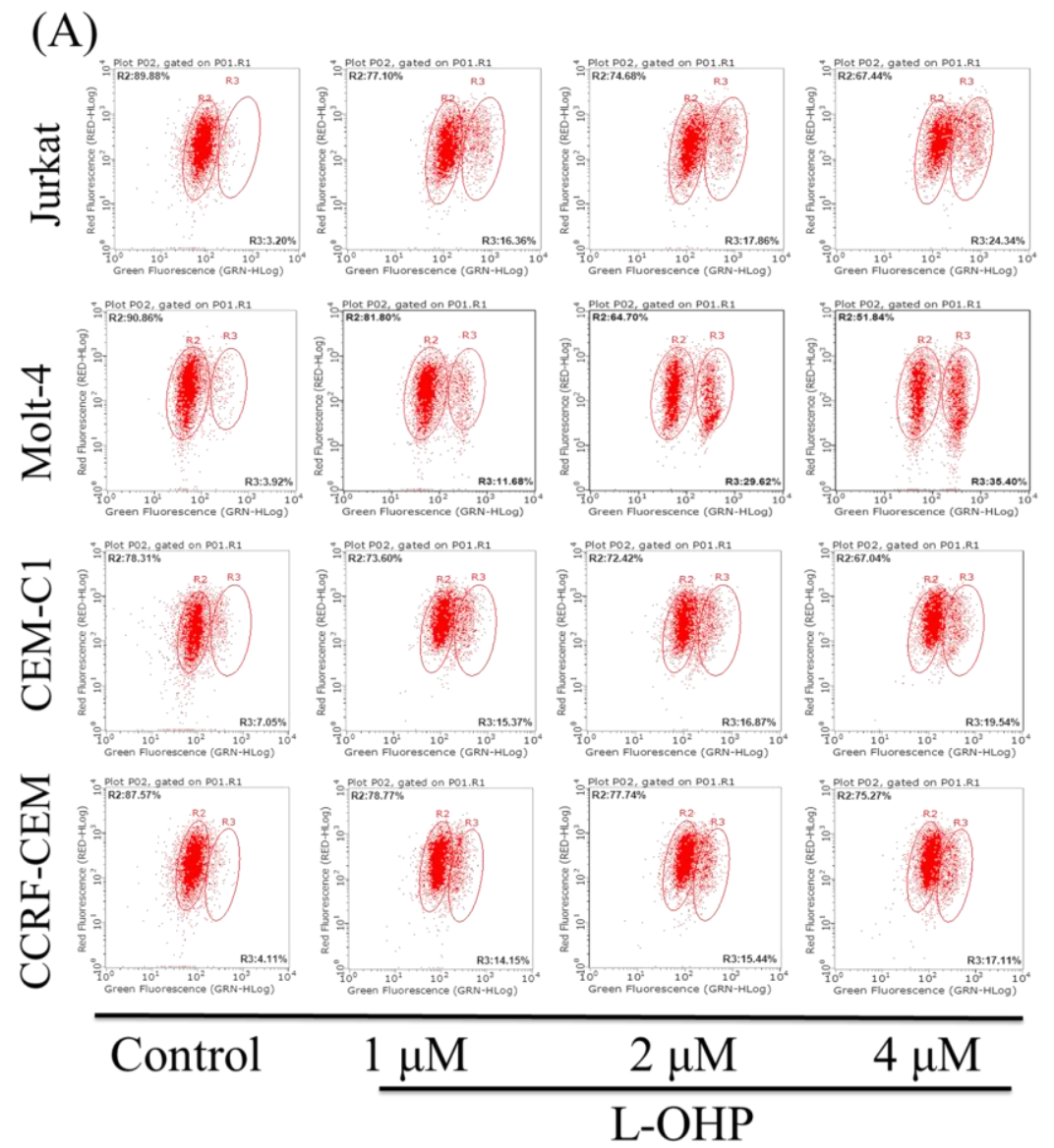

(B) Jurkat

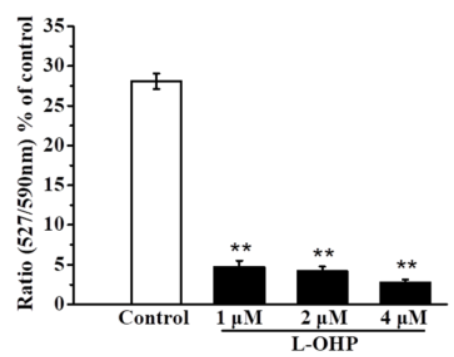

(D) CEM-C1

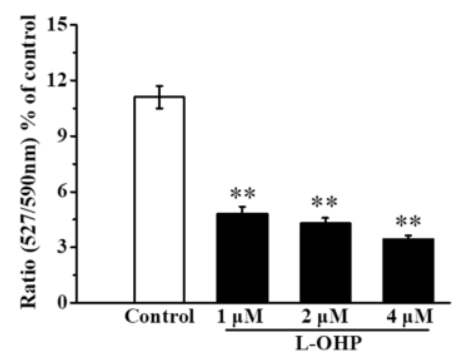

(C) MOLT-4



(E) CCRF-CEM

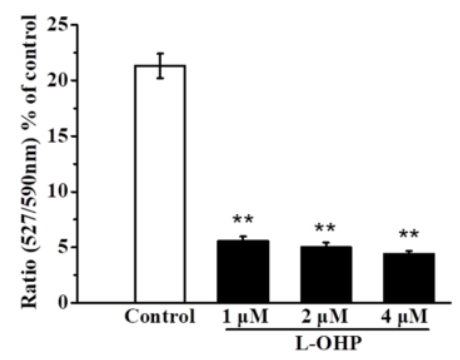

Figure 4 The effect of L-OHP on the activation of mitochondria in T-ALL cell lines. (A) Dot plot analysis of T-ALL cells treated with L-OHP. Representative flow cytometry results of JC-1 staining in T-ALL cell lines treated with L-OHP at concentrations of 1,2 and 4 $\mu \mathrm{M}$ for $48 \mathrm{~h}$. (B) to (E) Data summary, showing the percentage of red and green ratios in Jurkat, MOLT-4, CEM-C1 and CCRF-CEM cells. Red and green fluorescence represent aggregated (non-apoptotic) and monomeric (apoptotic) JC-1 staining, respectively. The data represents the mean \pm SD of three independent experiments. ${ }^{*} p<0.05$, ${ }^{* *} p<0.01$, vs. control group. 
(A)
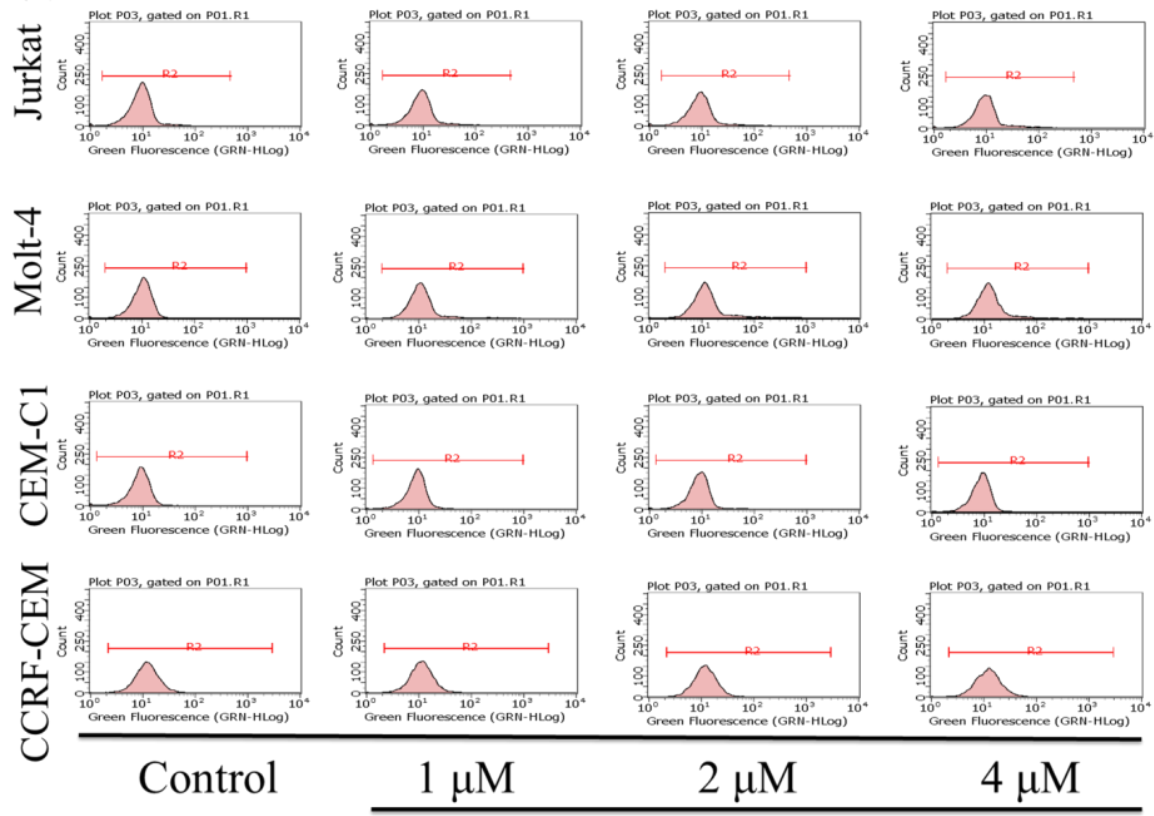

L-OHP

(B) Jurkat

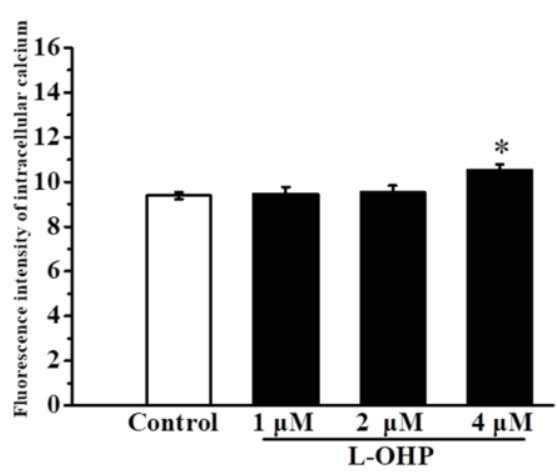

(D) CEM-C1

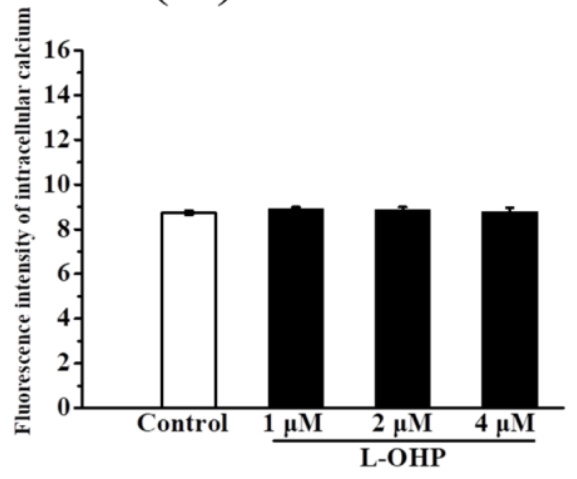

(C) MOLT-4

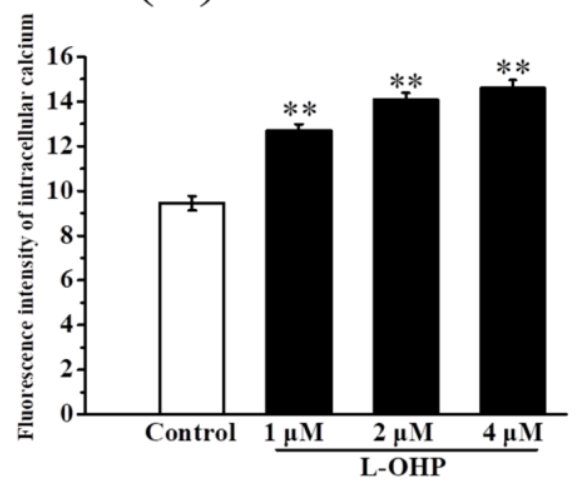

(E) CCRF-CEM

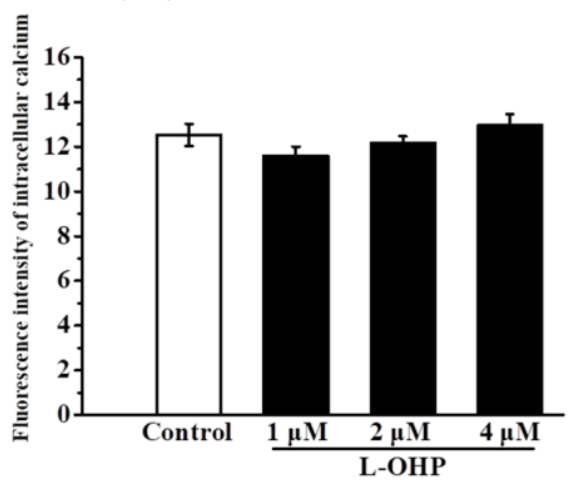

Figure 5 L-OHP increases the intracellular calcium concentration of T-ALL cell lines. (A) Histogram analysis of T-ALL cells treated with L-OHP. (B) to (E) The changes of intracellular calcium ion concentration in Jurkat, MOLT-4, CEM-C1 and CCRF-CEM cells treated with L-OHP for $48 \mathrm{~h}$. ${ }^{*} p<0.05,{ }^{* *} p<0.01 \mathrm{vs}$. control group. The data represents the mean $\pm \mathrm{SD}$ of three independent experiments. 


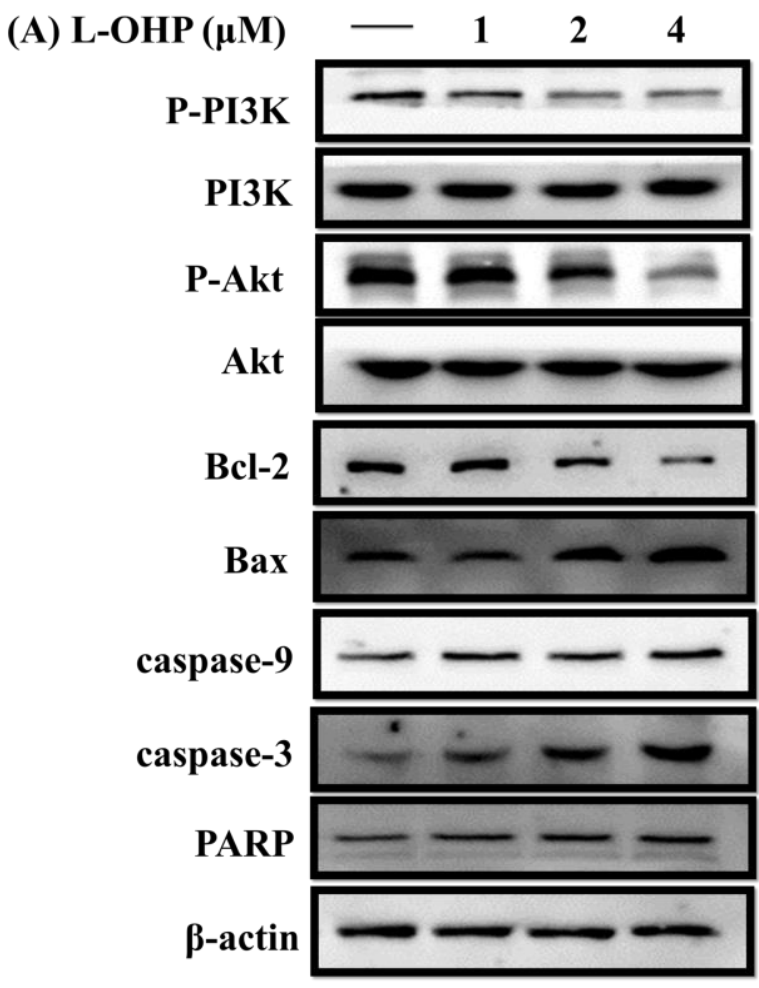

(B) P-PI3K/PI3K

(C) P-Akt/Akt

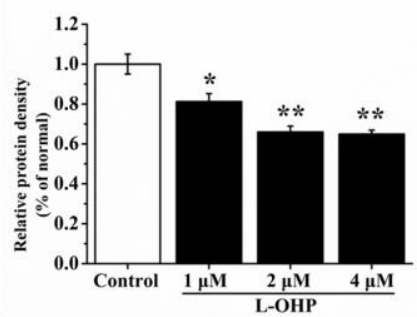

(D) Bcl-2/Bax

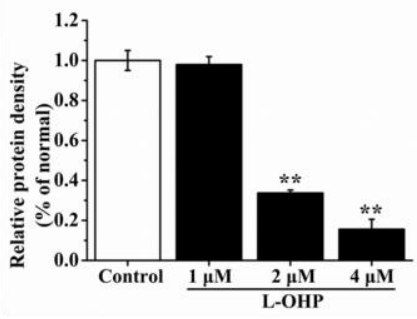

(F) caspase-3/ק-actin



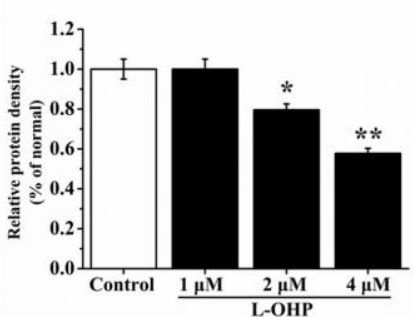

(E) caspase-9/ק-actin

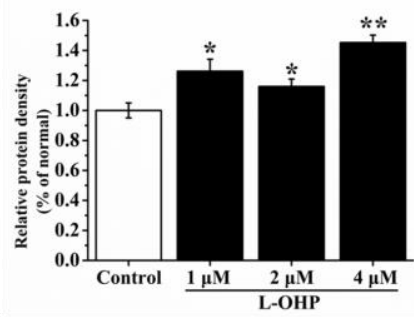

(G) PARP//-actin

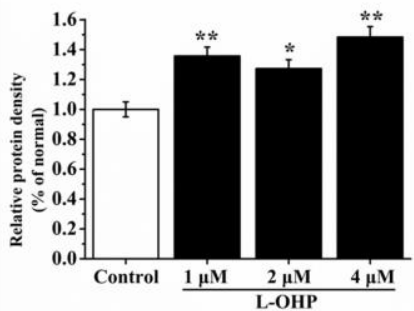

Figure 6 Oxaliplatin inhibited proliferation and promoted apoptosis in T-ALL cells through PI3K/Akt signaling pathways. $n=3,{ }^{*} p<$ $0.05,{ }^{* \star} p<0.01$ vs. Control group. 


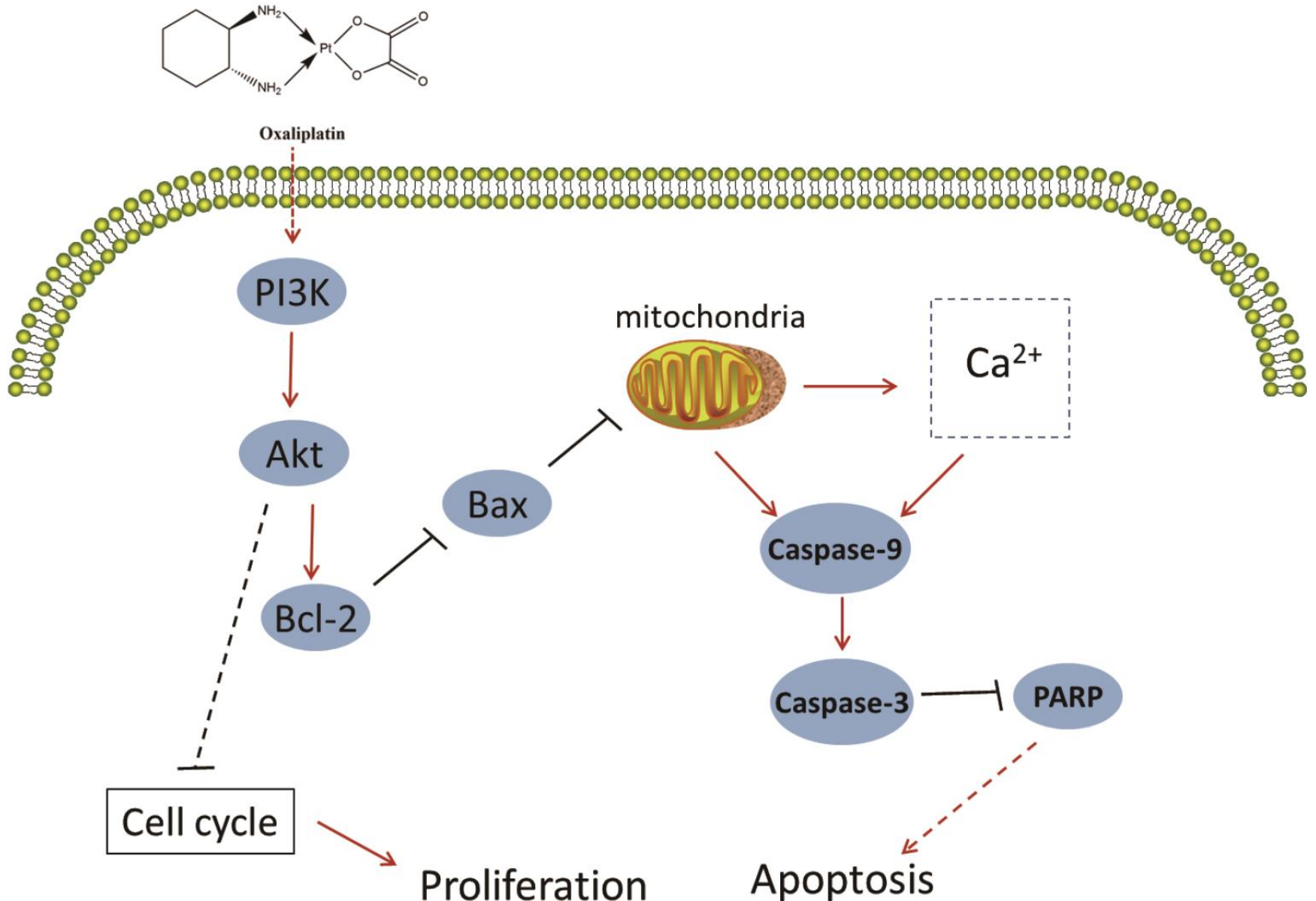

\section{T cell acute lymphoblastic leukemia cells}

Figure 7 Signal pathway of cell proliferation inhibition and apoptosis induced by Oxaliplatin in T-ALL cells.

induced cell proliferation inhibition apoptosis of T-ALL cells, we selected MOLT-4 cells that is more sensitive to L-OHP for subsequent experimental studies. Through optical microscope observation and Hoechst-33258 staining, L-OHP-induced reproductive status; adverse changes in cell morphology and nucleus can be visually observed.

Many studies have shown that the increase of intracellular $\mathrm{Ca}^{2+}$ plays a major role in triggering the apoptosis pathway. ${ }^{[25]}$ The destruction of MMP is one of the earliest intracellular events in the induction of apoptosis. ${ }^{[26,27]}$ Under the stimulation of apoptosis, MMP decreases and the mitochondrial permeability increases, leading to the release of cytochrome $\mathrm{C}$ and the activation of caspase- $9 .{ }^{[15,28]}$ Cancer cells can gain resistance to apoptosis by over expressing the anti-apoptotic protein $\mathrm{Bcl}-2$ or down-regulating the pro-apoptotic protein Bax. $^{[29]}$ Increasing the ratio of $\mathrm{Bax} / \mathrm{Bcl}-2$ will lead to the destruction of the integrity of mitochondrial membrane and the formation of mitochondrial permeability transition pores, thereby helping to release cytochrome $C$ and initiate the intrinsic apoptosis pathway. ${ }^{[30]}$ Our experimental results also verify the above conclusions. L-OHP induces apoptosis of MOLT-4 cells by increasing the ratio of $\mathrm{Bax} / \mathrm{Bcl}-2$ and the expression of caspase-9 protein.

The PI3K/Akt signaling pathway involves many cellular processes, such as cell growth, survival, transcription, translation, apoptosis, metabolism, motility and autophagy. ${ }^{[31]}$ In addition, it controls the different steps of normal $T$ cell development, differentiation and activation. Therefore, the dysregulation of this signal network may lead to the onset and progression of T-ALL and worsen the patient's prognosis. ${ }^{[32]}$ There is an evidence that the PI3K/Akt pathway contributes to cancerous transformation and maintains neoplastic cell proliferation. ${ }^{[33,34]}$ A research team has previously found that $\mathrm{PI} 3 \mathrm{~K}$ inhibition has strong cytotoxic effects on ALL cell lines and primary cells, indicating that targeting PI3K may be an attractive strategy for the treatment of ALL. ${ }^{[35-37]}$ Therefore, the expression of PI3K and the downstream transcription factors Akt were analyzed to explore whether the PI3K/Akt signaling pathway is inhibited by L-OHP. The results clearly showed that $\mathrm{L}-\mathrm{OHP}$ can inhibit the expression of $\mathrm{PI} \mathrm{K}$ signaling protein, indicating that the PI3K/Akt pathway may be an important target of L-OHP in T-ALL cells.

Based on the results of this study and previous reports, multiple signal pathways, by which L-OHP induced cell proliferation inhibition and apoptosis, were suggested as shown in Figure 7. L-OHP induced T-ALLs cells death by blocking the PI3K/Akt signaling pathway to inhibit cell proliferation, increase intracellular calcium concentration and cellular promote ROS-mediated mitochondrial-dependent apoptosis.

\section{Conclusions and Perspectives}

Our research shows that L-OHP has a significant 
cytotoxicity effect on T-ALL cells, which seems to be the result of cell proliferation inhibition and apoptosis. The observed cytotoxicity effect appears to be the result of inhibiting cell proliferation, cell cycle arrest, activating the pathways of mitochondrial biogenesis and increase in intracellular calcium. The treatment with L-OHP increased $\mathrm{Bcl}-2$ protein levels, decreased Bax and caspase- 9 proteins levels, and inhibited the activation of PI3K/Akt pathway. These results provide a promising theoretical basis for the treatment of patients with $T$ cell malignancy, especially those who are resistant to traditional chemotherapy.

\section{Acknowledgement}

This research was supported by the Applied Basic Research Project of Yunnan Province (No. 2018FB036), the Open Program of State Key of Phytochemistry and Plant Resources in West China (No. P2018-KF08), the China Postdoctoral Science Foundation (No. 2020M673586XB), and the Yunnan Major Natural Science Foundation (No. 2019ZF010).

\section{Author Contributions}

M. L., Y. W., G. C. and T. Z. carried out the concept, design, definition of intellectual content, literature search, data acquisition, data analysis, and manuscript preparation. A. K. and $\mathrm{Y}$. W. provided assistance for data acquisition, data analysis, and statistical analysis. L. T. and J. C. carried out literature search, data acquisition, and manuscript editing. Y. L. and M. Y. performed the manuscript review. All authors have read and approved the content of the manuscript.

\section{Conflict of Interest}

The authors declare no conflict of interest.

Copyright $(\odot 2021$ Mengcheng Li, Yongpeng Wang, Lei Tian, Afsar Khan, Yudan Wang, Yaping Liu, Meilian Yang, Jianxin Cao, Guiguang Cheng, and Tianrui Zhao. This article is an open access article distributed under the terms and conditions of the Creative Commons Attribution (CC BY) license (http://creativecommons.org/licenses/by/4.0/). The use, distribution or reproduction in other forums is permitted, provided the original author(s) or licensor are credited and that the original publication in this journal is cited, in accordance with accepted academic practice. No use, distribution or reproduction is permitted which does not comply with these terms.

\section{References}

[1] Xu, Y.; Li, X.; Su, X. Itraq-based proteomics analysis of the therapeutic effects of combined anticancer bioactive peptides and oxaliplatin on gastric cancer cells. Oncol. Rep. 2019, 43, 201-217.

[2] Kang, L.; Tian, Y.; Xu, S.; Chen, H. Oxaliplatin-induced peripheral neuropathy: Clinical features, mechanisms, prevention and treatment. J. Neurol. 2020, DOI: 10.1007/s00415-020-09942-w.

[3] Canta, A.; Chiorazzi, A.; Pozzi, E.; Fumagalli, G.; Monza, L.; Meregalli, C.; Carozzi, V. A.; Rodriguez-Menendez, V.; Oggioni, N.; Nasstrom, J.; Marmiroli, P.; Cavaletti, G. Calmangafodipir reduces sensory alterations and prevents intraepidermal nerve fibers loss in a mouse model of oxaliplatin induced peripheral neurotoxicity. Antioxidants 2020, 9, 594.

[4] Bonaccorso, P.; Bugarin, C.; Buracchi, C.; Fazio, G.; Gaipa, G. Single-cell profiling of pediatric $t$-cell acute lymphoblastic leukemia: Impact of pten exon 7 mutation on pi3k/akt and jak-stat signaling pathways. Cytom. Part. B-clin. Cy. 2020, 491-503.

[5] Li, G.; Gao, L.; Zhao, J.; Liu, D.; Hu, M. Lncrna anril/mir-7-5p/tcf4 axis contributes to the progression of $t$ cell acute lymphoblastic leukemia. Cancer Cell Int. 2020, 20, 335.
[6] Wu, K. N.; Zhao, Y. M.; He, Y.; Wang, B. S.; Du, K. L.; Fu, S.; Hu, K. M.; Zhang, L. F.; Liu, L. Z.; Hu, Y. X. Rapamycin interacts synergistically with idarubicin to induce t-leukemia cell apoptosis in vitro and in a mesenchymal stem cell simulated drug-resistant microenvironment via akt/mammalian target of rapamycin and extracellular signal-related kinase signalin. Leukemia Lymphoma 2014, 55, 668-676.

[7] Mcneer, J. L.; Bleyer, A. Acute lymphoblastic leukemia and lymphoblastic lymphoma in adolescents and young adults. Pediatr. Blood Cancer 2018, e26989.

[8] Jaime-Pérez, J. C.; Fernández, L. T.; Jiménez-Castillo, R. A.; Gómez-De León, A.; Cantú-Rodríguez, O. G.; Gutiérrez-Aguirre, C. H.; Gómez-Almaguer, D. Age acts as an adverse independent variable for survival in acute lymphoblastic leukemia: Data from a cohort in northeast mexico. Cl. Lymph. Myelom. Leuk. 2017, 590-594.

[9] Garcia, E. G.; Veloso, A.; Oliveira, M. L.; Allen, J. R.; Langenau, D. M. Prl3 enhances t-cell acute lymphoblastic leukemia growth through suppressing t-cell signaling pathways and apoptosis. Leukemia 2020, 1-12.

[10] Ko, R. H.; Ji, L.; Barnette, P.; Bostrom, B.; Hutchinson, R.; Raetz, E.; Seibel, N. L.; Twist, C. J.; Eckroth, E.; Sposto, R. Outcome of patients treated for relapsed or refractory acute lymphoblastic leukemia: A therapeutic advances in childhood leukemia consortium study. J. Clin. Oncol. 2010, 28, 648-654.

[11] Schrappe, M.; Hunger, S. P.; Pui, C. H.; Saha, V.; Gaynon, P. S.; Baruchel, A.; Conter, V.; Otten, J.; Ohara, A.; Versluys, A. B. Outcomes after induction failure in childhood acute lymphoblastic leukemia. New Engl. J. Med. 2012, 366, 1371-1381.

[12] Kong, Y.; Zhao, S.; Tian, H.; Hai, Y. Gas2 promotes cell proliferation and invasion and suppresses apoptosis in pediatric t-cell acute lymphoblastic leukemia and activates wnt/ $\beta$-catenin pathway. OncoTargets Ther. 2020, 13, 1099-1108.

[13] Malumbres, M.; Barbacid, M. Cell cycle, cdks and cancer: A changing paradigm. Nat. Rev. Cancer 2009, 9, 153-166.

[14] Roskoski, R. Cyclin-dependent protein serine/threonine kinase inhibitors as anticancer drugs. Pharmacol. Res. 2019, 139, 471-488.

[15] Wang, L.; Yao, L.; Li, X.; Chen, J.; Lou, C.; Wang, Y. Stephanthraniline a suppresses proliferation of hct116 human colon cancer cells through induction of caspase-dependent apoptosis, dysregulation of mitochondrial function, cell cycle arrest and regulation of akt $/ \mathrm{p} 38$ signaling pathways. J. Toxicol. Sci. 2019, 44, 523-533.

[16] Fan, M.; Chen, X.; Luo, X.; Zhang, H.; Liu, Y.; Zhang, Y.; Wu, J.; Zhao, C.; Zhao, P. Diversity of endophytic fungi from the leaves of vaccinium dunalianum. Lett. Appl. Microbiol. 2020, 71, 479-489.

[17] Ni, K.; Lan, G.; Veroneau, S. S.; Duan, X.; Song, Y.; Lin, W. Nanoscale metal-organic frameworks for mitochondria-targeted radiotherapy-radiodynamic therapy. Nat. Commun. 2018, 9, 4321.

[18] Mori, K.; Uchida, T.; Yoshie, T.; Mizote, Y.; Ishikawa, F.; Katsuyama, M.; Shibanuma, M. A mitochondrial ros pathway controls matrix metalloproteinase 9 levels and invasive properties in ras-activated cancer cells. FEBS J. 2019, 286, 459-478.

[19] Zhang, X.; Xu, L.; Yang, T. Mir-31 modulates liver cancer hepg2 cell apoptosis and invasion via rock $1 / f$-actin pathways. Onco Targets Ther. 2020, 13, 877-888.

[20] Jin, Q.; Li, R.; Hu, N.; Xin, T.; Zhu, P.; Hu, S.; Ma, S.; Zhu, H.; Ren, J.; Zhou, H. Dusp1 alleviates cardiac ischemia/reperfusion injury by suppressing the mff-required mitochondrial fission and bnip3-related mitophagy via the jnk pathways. Redox Biol. 2018, 14,576 .

[21] Li, Q.; Qiu, W.; Zhu, Q.; Zu, Y.; Deng, X.; Zhao, T.; Jiang, C.; Zhang, L. Camptothecin-20(s)-o-[n-(3'a,12' $\alpha$-dihydroxy-24'-carbonyl-5' $\beta$ cholan)]-lysine, a novel camptothecin analogue, induces apoptosis towards hepatocellular carcinoma smmc-7721 cells. Molecules 2011, 16, 7803-7814. 
[22] Orrenius, S. Mitochondrial regulation of apoptotic cell death. Toxicol. Lett. 2004, 149, 19-23.

[23] Verkhratsky, A.; Toescu, E. C. Endoplasmic reticulum $\mathrm{Ca}^{2+}$ homeostasis and neuronal death. J. Cell Mol. Med. 2003, 7, 351-361.

[24] Orrenius, S.; Zhivotovsky, B.; Nicotera, P. Calcium: Regulation of cell death: The calcium-apoptosis link. Nat. Rev. Mol. Cell Biol. 2003, 4, 552-565.

[25] Yoneyama, K. Validation of confocal laser scanning microscopy for detecting intracellular calcium heterogeneity in liver slices. J. Pharmacol. Tox. Met. 2001, 45, 187-193.

[26] Fu, Y.; Yi, Z.; Yan, Y.; Qiu, Z. Hydroxycamptothecin-induced apoptosis in hepatoma smmc-7721 cells and the role of mitochondrial pathway. Mitochondrion 2006, 6, 211-217.

[27] Han, J.; Goldstein, L. A.; Gastman, B. R.; Rabinowich, H. Interrelated roles for $\mathrm{mcl}-1$ and bim in regulation of trail-mediated mitochondrial apoptosis. J. Biol. Chem. 2006, 281, 10153-10163.

[28] Haga, N.; Fujita, N.; Tsuruo, T. Mitochondrial aggregation precedes cytochrome c release from mitochondria during apoptosis. Oncogene 2003, 22, 5579-5585.

[29] Raisova, M.; Hossini, A. M.; Eberle, J.; Riebeling, C.; Wieder, T.; Sturm, I.; Daniel, P. T.; Orfanos, C. E.; Geilen, C. C. The bax/bcl-2 ratio determines the susceptibility of human melanoma cells to cd95/fas-mediated apoptosis. J. Invest. Dermatol. 2001, 117, 333-340.

[30] Schwarz, M.; Andrade-Navarro, M. A.; Gross, A. Mitochondrial carriers and pores: Key regulators of the mitochondrial apoptotic program. Apoptosis 2007, 12, 869-876.

[31] Laplante, M.; Sabatini, D. M. Mtor signaling in growth control and disease. Cell 2012, 149, 274-293.
[32] Evangelisti, C.; Chiarini, F.; Cappellini, A.; Paganelli, F.; Fini, M.; Santi, S.; Martelli, A. M.; Neri, L. M.; Evangelisti, C. Targeting wnt/ $\beta$-catenin and $\mathrm{pi} / \mathrm{k} / \mathrm{akt} / \mathrm{mtor}$ pathways in t-cell acute lymphoblastic leukemia. J. Cell Physiol. 2020, 235, 5413-5428.

[33] Zhang, L. N.; Zhao, L.; Yan, X. L.; Huang, Y. H. Loss of g3bp1 suppresses proliferation, migration, and invasion of esophageal cancer cells via wnt/ $\beta$-catenin and pi3k/akt signaling pathways. J. Cell Physiol. 2019, 234, 20469-20484.

[34] Jefferies, M. T.; Cox, A. C.; Shorning, B. Y.; Meniel, V.; Griffiths, D.; Kynaston, H. G.; Smalley, M. J.; Clarke, A. R. Pten loss and activation of k-ras and $\beta$-catenin cooperate to accelerate prostate tumourigenesis. J. Pathol. 2017, 243, 442-456.

[35] Bressanin, D.; Evangelisti, C.; Ricci, F.; Tabellini, G.; Martelli, A. M. Harnessing the pi3k/akt/mtor pathway in t-cell acute lymphoblastic leukemia: Eliminating activity by targeting at different levels. Oncotarget 2012, 3, 811-823.

[36] Evangelisti, C.; Cappellini, A.; Oliveira, M.; Fragoso, R.; Barata, J. O. T.; Bertaina, A.; Locatelli, F.; Simioni, C.; Neri, L. M.; Chiarini, F. Phosphatidylinositol 3-kinase inhibition potentiates glucocorticoid response in b-cell acute lymphoblastic leukemia. J. Cell Physiol. 2018, 233, 1796-1811.

[37] Lonetti, A.; Antunes, I.; Chiarini, F.; Orsini, E.; Buontempo, F.; Ricci, F.; Tazzari, P. L.; Pagliaro, P.; Melchionda, F.; Pession, A. Activity of the pan-class i phosphoinositide 3-kinase inhibitor nvp-bkm120 in t-cell acute lymphoblastic leukemia. Leukemia 2014, 28, 1196-1206.

Received March 1, 2021

Accepted April 24, 2021 